\title{
Land Suitability Characterization for Crop and Fruit Production in Midlands of Tigray, Ethiopia
}

\author{
Kassa Teka $^{1^{*}}$ and Mulu Haftu ${ }^{2}$ \\ ${ }^{1}$ Department of Land Resource Management and Environmental Protection, Mekelle \\ University, P.O. Box: 231, Mekelle (*kassateka@yahoo.com) \\ ${ }^{2}$ Wukro St.Mary’s Integrated Rural Development Project, P.O.Box: 12, Wukro
}

\begin{abstract}
The aim of this evaluation was to find out which parcels of land may best support the different crops and fruits commonly grown by the local farmer and recommend these results to the local stakeholder for an increased yield. The focus was on food crops and fruits those can be used to alleviate poverty and improve nutrition in farm households, with the highest priority assigned to crops and fruits already well established in the area. Remote sensing (ILWIS3.3) and GIS (ArcView3.2) soft wares were used to establish the land unit maps of the area. The land suitability assessment for annual crops and fruit trees was carried out with the use of the parametric methodology. Results showed that the cultivated land under question is marginally suitable (S3) for Zea mays L.; $91.5 \%$ of the land is S3 for Cicer arietinium, Psidium guajava and Mangifera indica; 68.9\% is S3 for Persea americana and Hordeum vulgare L.; 77.4\% is S3 for Carica papaya L. and Sorghum bicolor L. Moench. The use of land according to its suitability class or mitigating the limiting factors is, therefore, paramount for increased production.
\end{abstract}

Key words: Suitability, Crops, Fruits, Midlands, Cultivated land, Tigray.

\section{INTRODUCTION}

Nowadays, the population of the planet is growing dramatically (Liu and Chen, 2006). However, the potential of the land for crop production to satisfy the demand of the ever increasing population is declining as the result of sever soil degradation (Lal, 1994). Empirical studies indicate that severe degradation of soils' productive capacity has occurred on over $10 \%$ of the Earth's vegetated land as a result of soil erosion, excessive tillage, and overgrazing etc. (Lal, 1994). Fuelled by the combined effects of anthropogenic activities, land degradation in Ethiopia is hastening desertification (Cesen, 1986).

In order to meet the increasing demand for food the farming community has to produce more and more. However, under present situation, where land is a limiting factor, it is impossible to bring more area under cultivation to satisfy the growing demand (Fischer et al., 2002). Teklu (2005) stated that the need for increased agricultural productivity to address the persistent poverty and food insecurity in developing countries is intensified. For instance, AlMashreki et al. (2011) assessed the suitability of land in Ibb Governorate, Republic of Yemen for sorghum and found about $61 \%$ of the area was highly to marginally suitable. Another study in Legambo woreda, Ethiopia showed nearly $60 \%$ of the area was highly to marginally 
suitable for agriculture (Henok, 2010). The result of the study in Legambo woreda, Ethiopia for different crops was found to be $85 \%$ suitable for wheat and $65 \%$ for Maize.

Generally, the most important limiting factors in wheat and barley productions in the different sites under review included physical properties of the soil such as soil texture and soil depth. Briza et al. (2001) also found lime content, soil texture and slope as the most limiting factors of land suitability for maize production in the Province of Ben Slimane, Morocco.

Considering the rapid growth of the world's populations, which is in its turn a limiting factor to the arable lands around the world, the need for effective and efficient application of the croplands have been felt more than ever (Teklu, 2005; Behzad et al., 2009). Hence, much attention is given to selection of crops, which suits an area the best. The concept of sustainable agriculture involves producing quality crops in an environmentally friendly, socially acceptable and economically feasible way (Addeo et al. 2001). Suitability, therefore, is a measure of how well the qualities of a land unit match the requirements of a particular form of land use (FAO, 1976).

The best use for land is a function of crop requirements and soil/land characteristics. Detailed soil spatial information is, therefore, required for many land management application (Burrough, 1996). However, this information was lacking to take up proper planning in the study area. Hence, it is necessary to evaluate the soil in a given agro-ecological unit for crop production under defined management system. Accordingly, potentials and limitations of soils were assessed using field survey to support the evaluation. Land management practices that can control the processes of land degradation, and their efficiency in this respect, will largely govern sustainability of a given land use (Smyth and Dumanski, 1993). Hence, sustainable agriculture would be achieved if lands be categorized and utilized based upon their different uses (FAO, 1984).

The aim of this evaluation was to find out which parcels of land may best support the different crops commonly grown by the local farmer. The focus was on food crops that can be used to alleviate poverty and improve nutrition in farm households, with the highest priority assigned to crops already well established in the area.

\section{STUDY AREA}

The study area, Korir watershed, is located in Kilte-Awlae'lo woreda, eastern zone of Tigray (Fig.1). The total size of the area is $14.64 \mathrm{~km}^{2}, 1464$ hectares, and is located where the grid 
coordinate is at 564141E \& $1517446 \mathrm{~N}$ and 568959E \& 1519706N. The mean annual rainfall is about $466 \mathrm{~mm}$ and the maximum and minimum temperature range from $23-28^{\circ} \mathrm{C}$ and from $9-14^{\circ} \mathrm{C}$, respectively (National Meteorological Service Agency Wukro Sation). The area is classified as Midland or Dry Weyna-Dega agro-ecological zone. The topographic features of the watershed include mountain, cliff escarpments, hills and plain (1500 - 2300 meters above sea level) (SFPT, 2003). The dominant tree species of the area is Acacia etbica which, account to more than 90\% (SFPT, 2003).

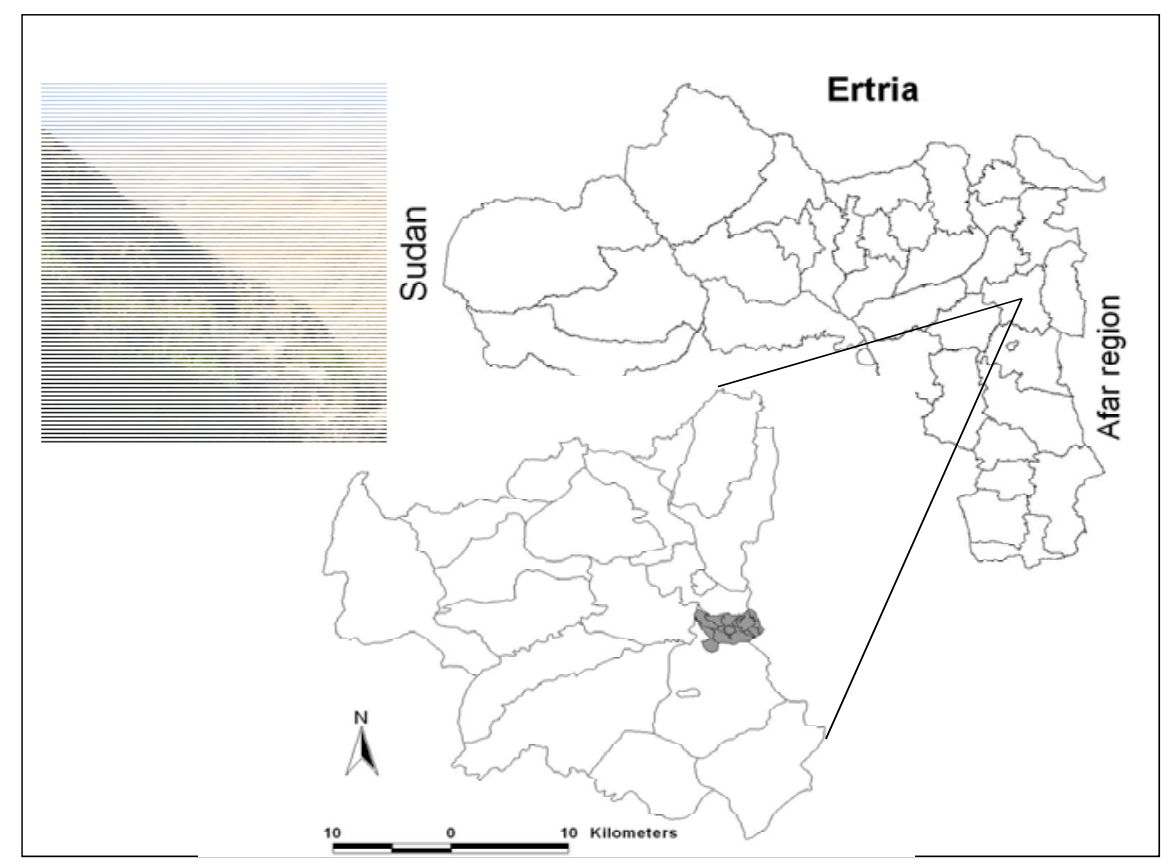

Figure 1. The study watershed (shaded and photo).

The agricultural area of the watershed is 724.5ha. Annual crops: Cicer arietinium, Hordeum vulgare L., Zea mays L., Sorghum bicolor L. Moench, and fruit trees: Citrus spp., Persea americana, Psidium guajava, Carica papaya L, Olives and Mangifera indica are the most important for the economy and subsistence of the families in the area since most families earn their livelihoods from the cultivation of these crops and fruits. Livestock farming constitutes a significant financial reserve for the majority of the farmers.

\section{METHODOLOGY}

The watershed was classified into homogeneous units, land units, based on topographic position (plateau, slopping, foot slope and valley bottom) and land use (non-agricultural, rainfed agriculture and irrigated agriculture) of the area. Each land unit was delineated through 
Aerial Photo Interpretation (API, 1994) at 1:50,000 scales, digitized on screen using ILWIS3.3 and Arc view GIS3.2 software and improved with ground truth. The land unit map was used as a guide in the field survey, soil sampling and, in turn, developing a more detailed soil map following a re-interpretation of field observation and soil analysis. The main focus of the study was on existing cultivated lands. The land evaluation was determined based upon topography and soil characteristics. The topographic characteristics included slope while soil properties included soil texture, depth, salinity, drainage and carbonate content. Also, soil properties such as Cation Exchange Capacity (CEC), organic mater (\%OM) and $\mathrm{pH}$ were considered in terms of soil fertility (Sys et al., 1991). A soil profile pit was opened in each land unit, four profile pits in total, and described using soil description guideline (FAO, 1990). Soil classification was made based on FAO (1998). Extent of erosion was observed from extent of gully cut, exposed rock outcrop, sedimentation into the river course and existing vegetation cover. Moreover, surface stoniness (\% area) was measured at field taking representative sample plots in each land unit.

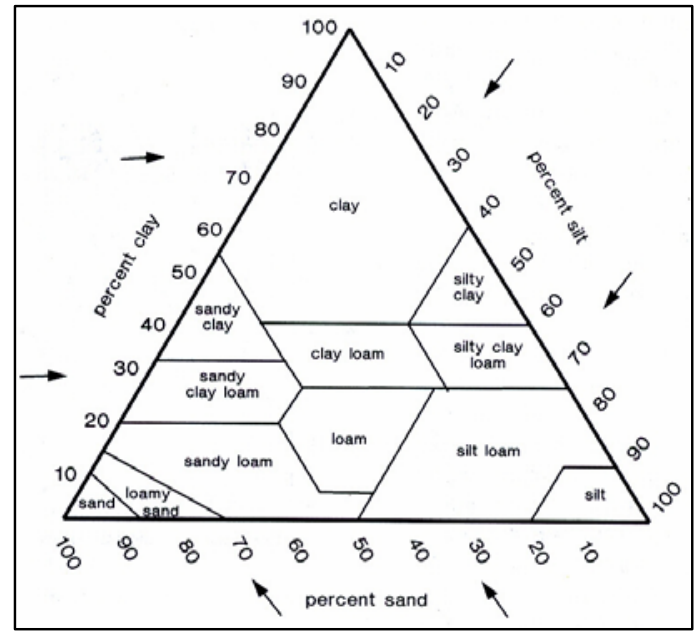

Figure 2. Soil Textural Triangle.

Table 1. Interpretation ratings for chemical soil characteristics (Hunting, 1976).

\begin{tabular}{|llllll|}
\hline & Very low & Low & Medium & High & Very high \\
\hline EC $(\mathrm{dS} / \mathrm{m})$ & $0-2$ & $2-4$ & $4-8$ & $8-16$ & $>16$ \\
\hline $\mathrm{CEC}(\mathrm{cmol}(+) / \mathrm{kg}$ & $0-3$ & $3-7$ & $7-15$ & $15-30$ & $>30$ \\
\hline Ntot $(\mathrm{g} / 100 \mathrm{~g})$ & $0-0.1$ & $0.1-0.2$ & $0.2-0.3$ & $0.3-0.4$ & $>0.4$ \\
\hline $\mathrm{Ctot}(\mathrm{g} / 100 \mathrm{~g})$ & $0-0.6$ & $0.6-1.2$ & $1.2-3.0$ & $3-8.7$ & $>8.7$ \\
\hline \multirow{2}{*}{$\mathrm{pH}(\mathrm{H} 2 \mathrm{O})$} & $5-6$ & $6-7$ & $7-8$ & $8-9$ & $9-10$ \\
& $\begin{array}{l}\text { Moderately } \\
\text { acid }\end{array}$ & Slightly acid & $\begin{array}{l}\text { Slightly } \\
\text { alkaline }\end{array}$ & $\begin{array}{l}\text { Moderately } \\
\text { alkaline }\end{array}$ & $\begin{array}{l}\text { Strongly } \\
\text { alkaline }\end{array}$ \\
\hline $\mathrm{CaCO}(\mathrm{g} / 100 \mathrm{~g})$ & $0-0.5$ & $0.5-2.0$ & $2.0-5.0$ & $5.0-15$ & $>15$ \\
\hline Pav $(\mathrm{g} / 100 \mathrm{~g})$ & $0-0.4$ & $0.4-1.3$ & $1.3-2.6$ & $2.6-5.3$ & $>5.3$ \\
\hline
\end{tabular}


Nine composite soil samples from demarcated horizons of the four profile pits were taken for soil physico-chemical analysis of the following parameters: Soil texture, soil $\mathrm{pH}, \mathrm{CaCO}_{3}$, organic carbon (\%), salinity or EC $\left(\mathrm{dSm}^{-1}\right)$, cation exchange capacity (CEC), total nitrogen and available phosphorous. A soil textural triangle (Fig. 2) was used to determine soil textural class from the percentages of sand, silt, and clay in the soil. These soil characteristics were matched with the interpretation ratings for soil chemical characteristics (Table 1) (Hunting, 1976).

The suitability of the different land units for agriculture lands were evaluated based on the matching table (Table 2) developed by Van Diepen et al. (1991). In a soil evaluation for agricultural purpose, it does not suffice to choose only one property rather it requires a group of properties possibly the more the better (van Diepen, 1991). The properties to choose depend on the proposed use of the soil (Table 2).

Table 2. Environmental indicators of the degree of suitability of soils for agricultural use (van Diepen et al., 1991).

\begin{tabular}{|c|c|c|c|c|}
\hline & $\begin{array}{l}\text { Very } \\
\text { favourable }\end{array}$ & Favourable & Unfavourable & $\begin{array}{l}\text { Very } \\
\text { unfavourable }\end{array}$ \\
\hline $\begin{array}{l}\text { Effective depth, } \\
\text { cm }\end{array}$ & $>120$ & $120-70$ & $70-30$ & $<30$ \\
\hline Texture & balanced & moderate heavy & heavy & light \\
\hline Internal drainage & Without hydro & Hydro $>80 \mathrm{~cm}$ & Hydro $>40 \mathrm{~cm}$ & Hydro a $0 \mathrm{~cm}$ \\
\hline $\begin{array}{l}\text { Organic matter, } \\
\%\end{array}$ & $>5$ & $5-2$ & $2-1$ & $<1$ \\
\hline CEC, $\mathrm{cmol}_{(+)} \mathrm{kg}^{-1}$ & $>40$ & $40-20$ & $20-10$ & $<10$ \\
\hline $\mathrm{pH}$ & $7.3-6.7$ & $6.7-5.5$ or $7.3-8.0$ & $5.5-4.5$ or $8.0-9.0$ & $<4.5$ or $>9.0$ \\
\hline Carbonates, \% & $<7$ & $7-15$ & $15-25$ & $>25$ \\
\hline Salinity, $\mathrm{dSm}^{-1}$ & $<2$ & $2-6$ & $6-12$ & $>12$ \\
\hline Slope, \% & $<4$ & $4-10$ & $10-25$ & $>25$ \\
\hline $\begin{array}{l}\text { Surface } \\
\text { stoniness, \% }\end{array}$ & $<2$ & $2-20$ & $2-20$ & $>50$ \\
\hline $\begin{array}{l}\text { Surface } \\
\text { rockiness, \% }\end{array}$ & $<2$ & $2-20$ & $2-20$ & $>50$ \\
\hline $\begin{array}{l}\text { Erosion, } \\
\text { Tm/ha/year }\end{array}$ & $<10$ & $10-20$ & $20-60$ & $>60$ \\
\hline Ploughing & no problems & limited & severe & very severe \\
\hline Precipitation, mm & $>1000$ & $1000-600$ & $600-300$ & $<300$ \\
\hline $\begin{array}{l}\text { Frost, } \mathrm{T}^{\mathrm{a}}<0^{\circ} \\
\text { months }\end{array}$ & $<1$ & $1-3$ & $3-6$ & $>6$ \\
\hline
\end{tabular}

Texture: balanced = loam, silt loam, sandy clay loam; moderately heavy = sandy clay, clay loam, silty clay loam, silt; heavy = clay, silty clay; light = sand, loamy sand. Internal drainage: hydro = hydromorphy. $C E C=$ cation-exchange capacity. Ploughing: no problems = ploughing is possible at any time of the year; limited = not possible during wet periods, clayey soils; severe = only in dry periods, soils very clayey. Very severe $=$ not possible due to steep slopes or high groundwater table; Precipitation = Annual precipitation. 
Requirements for each crop recommended by Sys et al (1993) were used. The mathematical method adopted to process all data was based on a formula below (FAO, 1984). Suitability classification was then made based on suitability index (Table 3).

$$
\text { Finalscore }=\frac{\sum \text { parametereswithweight }>1}{\sum \text { weight }>1} \times \text { productofparameterswithweight }=1
$$

Table 3. Land suitability index.

\begin{tabular}{|lll|}
\hline Class & Index & Description \\
\hline S1 & $0.8-1$ & Highly suitable \\
\hline S2 & $0.8-0.6$ & Moderately suitable \\
\hline S3 & $0.6-0.45$ & Marginally suitable \\
\hline N & $0.45-0$ & Unsuitable \\
\hline
\end{tabular}

\section{RESULTS AND DISCUSSIONS}

\subsection{Land Unit and Land Use Identification and Soil Classification}

For the purpose of soil classification five land use types in the watershed and then four land units in the arable land were identified. The bases for classification were the topographic position of the land (i.e. plateau, foot slope and valley bottom) and the morphology of the soil (Fig. 3). The major land uses of the watershed are cultivated (49.5\%), grass land (4.8\%), bush land (31.3 \%), degraded bush land (10.6 \%) and built-up area (3.8 \%).

The major soil types found in the study watershed are Leptosol (107.1ha) and Epileptic Cambisol (humic) at the plateau (227.5ha) with 2 - 5\% slope; endoleptic Cambisol (171.2ha), calcaric Leptosol (humic), (27.1ha) and calcaric Leptosol (128.6ha) at the side slope with 30 - 50\% slope; epi-Leptic Cambisol (calcaric), (24.9ha) and calcaric Cambisol (474.8ha) at the foot slope with 8 - 15\% slope; Regosol (44.85ha) and calcaric Vertisol, (163.6ha) at the valley bottom with 3 - 8\% slope (Figure 2). However, major soils found in the investigated arable land are: Leptosol at the plateau (LU-4); calcaric Cambisol (LU-2) at the foot slope; Regosol (LU-3), calcaric Vertisol and LU-1 at the valley bottom (Fig. 4).

The soil in LU-1 has a very low EC and Ntotal; low available phosphorous (Pav); medium total organic carbon content; high $\mathrm{CaCO}_{3}$; very high CEC with moderately alkaline $\mathrm{pH}$. Soils in LU-2 have very low EC; low Ntotal; medium organic carbon content; high Pav and CEC; medium alkaline pH. Soils in LU-3 have very low EC and Ntotal; low CEC and total organic carbon content; high $\mathrm{CaCO}_{3}$ and Pav; slightly acidic pH. However, major soils in LU-4 have very low EC, CEC, and Ntotal; low organic carbon content; high $\mathrm{CaCO}_{3}$ and Pav; medium $\mathrm{pH}$. 
The area is highly degraded. Sheet and rill erosions are very common in the cultivated land, grazing and bush land while gullies are widely spread on the sloppy hill side parts of the catchment.

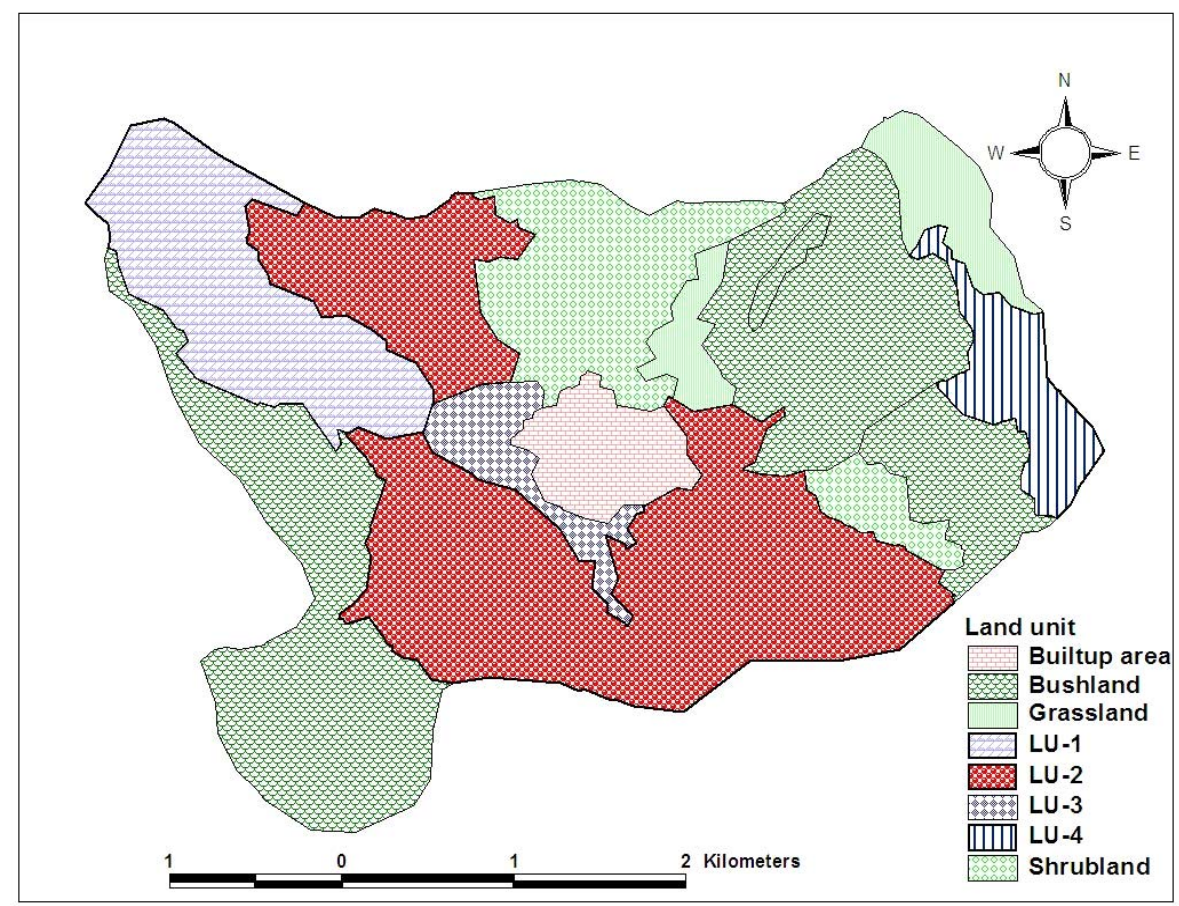

Figure 3. Land unit map of the study area.

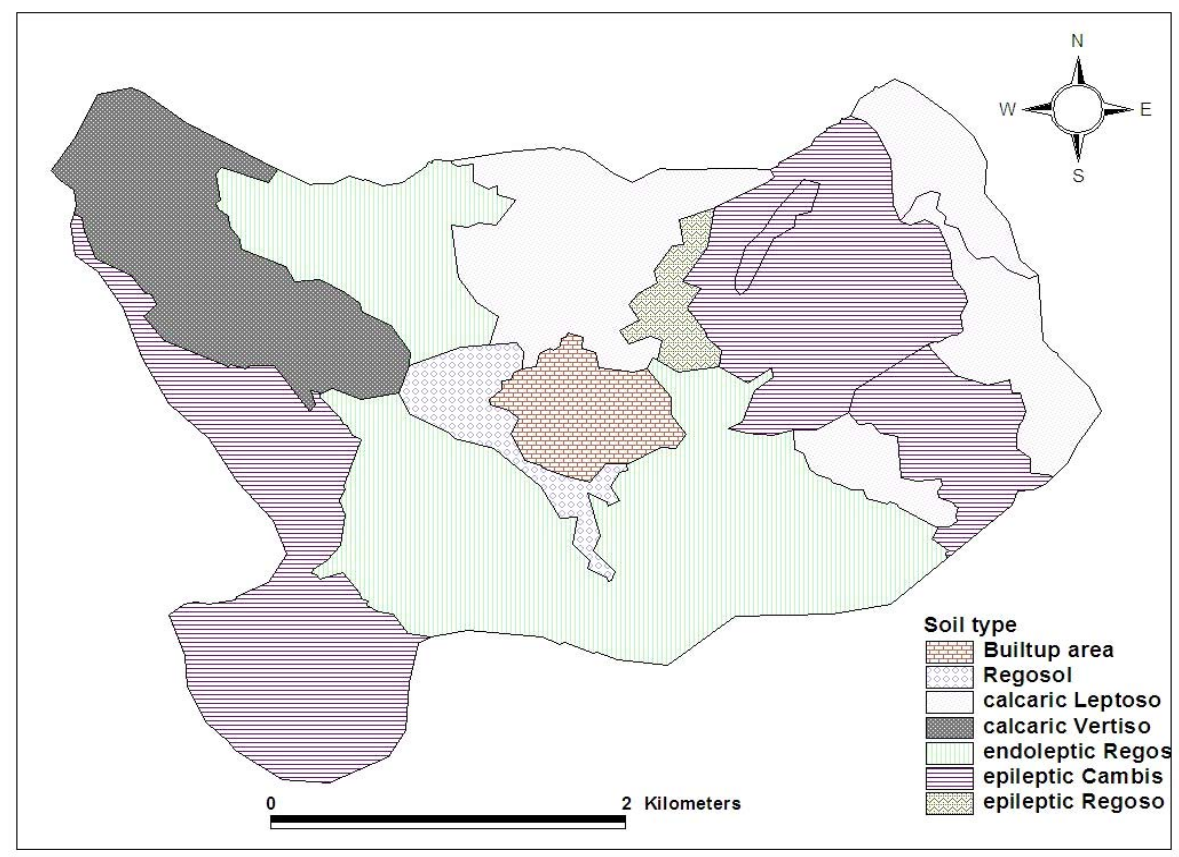

Figure 4. Soil types of the study area. 


\subsection{Land Suitability for Agricultural Purpose}

Most of the land characteristics considered in the evaluation of land unit one, land currently under irrigation, range from very favorable to favorable for agricultural purposes. The $\mathrm{pH}$ of the soil, moderately alkaline, is the limiting factor. A high $\mathrm{pH}$, up to about $\mathrm{pH}$ 8.0, would probably create severe micronutrient deficiencies such as iron, zinc and manganese and result in a general yellowing and poor growth (Mullen et al., 2007). Hence, the pH needs to be corrected for effective use of the soil for agricultural purposes. In most cases, irrigated soils in particular due to the cost of fertilizer, the $\mathrm{pH}$ can be lowered simply by using fertilizers containing ammonium-N. Ammonium sulfate and sulfur-coated urea are two of the best choices for acidifying soils (Mullen et al., 2007).

The suitability of the land under land unit two for agricultural purpose is limited by effective soil depth and $\mathrm{pH}$ which made the land unfavorable and the presence of high carbonate level made it very unfavorable. Van Dipen et al (1991) suggested an effective soil depth of $>70 \mathrm{~cm}$ for proper agricultural production (Table 2). Although, Carbonates contribute to soil organic carbon (SOC) protection and aggregate formation and stabilization (Bronick and Lal, 2005), the amount exceeding $15 \%$ leads to hard surface formation and affecting crop nutrient availability in the soil (Van Diepem et al., 1999).

Most of the land characteristics considered, except CEC (very unfavorable) and OM (unfavorable), are ideal for agriculture in land unit three. This is in line to the study by Kay and Angers (1999). Kay and Angers suggested that soil organic C levels less than 1\% may be unable to attain maximum agricultural yields, regardless of the soil type.

Land unit four is considered as very unfavorable for agriculture. These soils are not suitable for crops with stubbles that are easily detached and leaving the soil surface bare (Moore, 2001). The determinant land characteristic for land unit four is the organic mater which made the land unit unfavorable. The land is very unfavorable due to effective soil depth, texture and CEC. All land units in the study watershed, except land unit four, are with in the moderate to favorable suitability. This is inline to the study of Henok (2010), in which he found about $60 \%$ of the land in Legambo woreda, Ethiopia, suitable for agriculture.

\subsection{Land Suitability for Crops and Fruit Trees}

The evaluation class for the crops' suitability ranges from highly suitable to permanently not suitable. This is due to the different condition that the crops require for their developments in the local area in question (Table 4). 
Table 4. Soil chemical characteristics of the Korir watershed.

\begin{tabular}{|c|c|c|c|c|c|c|c|c|c|}
\hline$L U$ & $\begin{array}{l}\text { Horizon } \\
\text { depth }(\mathrm{cm})\end{array}$ & $\begin{array}{l}E C(d \\
S / m) \\
\end{array}$ & $p H$ & $\begin{array}{l}\text { Textural } \\
\text { Class }\end{array}$ & $T N(\%)$ & $\begin{array}{l}\mathrm{CaCO}_{3} \\
(\%)\end{array}$ & $\begin{array}{l}\text { Pava } \\
\text { (ppm) }\end{array}$ & $\begin{array}{l}O M \\
(\%)\end{array}$ & $\begin{array}{l}C E C \\
(\mathrm{Cmol} / \mathrm{kg})\end{array}$ \\
\hline \multirow[t]{3}{*}{1} & $0-16$ & 0.32 & 8.10 & SC & 0.08 & 11.32 & 1.99 & 3.09 & 40.68 \\
\hline & $17-35$ & 0.20 & 8.20 & SCL & 0.05 & 11.73 & 0.36 & 2.40 & 44.82 \\
\hline & $36-150$ & 0.34 & 8.37 & CL & 0.05 & 11.73 & 0.83 & 2.37 & 45.72 \\
\hline \multirow{2}{*}{2} & $0-15$ & 0.19 & 8.18 & C & 0.12 & 30.74 & 5.32 & 3.33 & 21.6 \\
\hline & 16-55 & 0.27 & 8.22 & $S$ & 0.08 & 21.84 & 1.99 & 2.91 & 30.42 \\
\hline \multirow{3}{*}{3} & $0-11$ & 0.10 & 8.20 & SL & 0.03 & 8.90 & 5.32 & 1.27 & 4.32 \\
\hline & $12-32$ & 0.05 & 7.88 & SL & 0.03 & 8.90 & 2.84 & 1.10 & 8.82 \\
\hline & 33-150 & 0.05 & 7.86 & SL & 0.03 & 8.49 & 3.78 & 1.06 & 6.66 \\
\hline 4 & $0-29$ & 0.10 & 7.03 & $\mathrm{~S}$ & 0.02 & 7.68 & 3.61 & 1.44 & 2.7 \\
\hline
\end{tabular}

Note: Sandy Clay -SC, Sandy Clay Loam -SCL, Clay Loam -CL, C-Clay, S-Sand, Sandy Loam-SL

Majority, 91.54\%, of the cultivated land is classified as marginally suitable and $8.5 \%$ as permanently not suitable for Cicer arietinium, Psidium guajava and Mangifera indica. Citrus spps and Persea americana are marginally suitable in $28.8 \%$ and $68.9 \%$ of the cultivated land respectively and permanently not suitable in the remaining cultivated area. Hordeum vulgare L. is moderately suitable in $22.6 \%$, marginally suitable in $68.9 \%$ and permanently not suitable in $8.5 \%$ of the cultivated land. Zea mays $L$ is marginally suitable in the whole cultivated land. Olives is marginally suitable and moderately suitable in $22.6 \%$ and $6.2 \%$ respectively and permanently not suitable in $71.2 \%$ of the cultivated land. $77.4 \%$ of the cultivated land is marginally suitable and $22.58 \%$ highly suitable for Carica papaya L. and Sorghum bicolor L. Moench. No area is classified as highly and moderately suitable for Cicer arietinium, Zea mays L, Persea americana, Psidium guajava, Mangifera indica and Citrus spps. (Table 5). Researches in other areas showed similar result. For instance, Henok (2001), in his research in Legambo woreda, Ethiopia found that $7.5 \%$ was highly suitable, $23 \%$ moderately suitable, 44.4\% marginally suitable, 22\% temporary unsuitable and 3.1\% was permanently unsuitable for wheat production. Moreover, 8.5\% was highly suitable, $27.4 \%$ moderately suitable, 29.4\% marginally suitable, $24.2 \%$ temporary unsuitable and $10.5 \%$ was permanently unsuitable for maize production (Henok, 2001). Yasmina et al (2001) in their research in the 
province of Ben Slimane, Morocco, also showed that much of the croplands of the region were in critical condition for wheat, barley, pea and been.

Table 5. Land suitability for the common crops \& fruits grown in the study area.

\begin{tabular}{|c|c|c|c|c|}
\hline \multirow[t]{2}{*}{ Crop type } & \multicolumn{4}{|c|}{ Land Unit } \\
\hline & 1 & 2 & 3 & 4 \\
\hline Chickpea & S3 & S3 & S3 & N2 \\
\hline Sorghum & S1 & S3 & S3 & S3 \\
\hline Maize & $\mathrm{S} 3$ & S3 & S3 & S3 \\
\hline Barley & $\mathrm{S} 2$ & S3 & S3 & N2 \\
\hline Citrus & S3 & N2 & S3 & N2 \\
\hline Avocado & N2 & S3 & S3 & N2 \\
\hline Guava & S3 & S3 & S3 & N2 \\
\hline Mango & S3 & S3 & S3 & $\mathrm{N} 2$ \\
\hline Papaya & S1 & S3 & S3 & S3 \\
\hline Olives & $\mathrm{S} 2$ & N2 & S3 & N2 \\
\hline
\end{tabular}

The unsuitability of the above land units for the cultivation of the analyzed crops could be explained by their type of soil which, varies from very sandy to heavy clayey soils and soil depth which varies from very shallow to very deep, slope which varies from gentle to steep slope and surface stoniness which varies from little to very high stoniness (Table 4).

The coarse texture and shallow depth of the soils in land units two and four are the main limiting factors for crop and fruit growth in the study watershed. This is in line to the study by Francesco et al. (2003) and Yasmina et al. (2001). Francesco and his group, in the Thies region in Senegal, showed that the northwest part of the region was unsuitable to maize, sorghum and pea due to the dominancy of sandy soils. More over, Yasmin et al. (2001) found that the most limiting factors were soil texture, soil depth and drainage. Similar to the study of Sokol et al. (2004), on Oud Rmel Catchment of Tunisia, the most influential limiting factors to land units one and three were alkaline $\mathrm{pH}$ and the excessive amount of the soil calcium carbonate. Lime content and partly soil texture were the most important factors in wheat and barely production in the study area. This is in line to the study of (Behzad et al., 2009). Brizia et al. (2001) also investigated that the most limiting factors of the land suitability in the province of Ben Slimane, Morocco, in wheat and barley productions include physical characteristics such as soil texture, soil depth and drainage.

\section{CONCLUSION}

The major cultivated soil types found in the study watershed are Leptosol (LU- 4); calcaric Cambisol (LU-2); Regosol (LU-3) and calcaric Vertisol (LU-1). The properties of these soils 
and other land characteristics affected the potential of the land for agriculture. The major limiting land characteristics for agricultural productivity of the different land units in the watershed are $\mathrm{pH}$ in LU-1; effective soil depth, $\mathrm{pH}$, texture and carbonate in LU-2; cation exchange capacity and organic matter in LU-3; organic mater, effective soil depth, texture and cation exchange capacity in LU-4.

The study results showed that $6.2 \%$ of the area is suitable for all the crops reviewed; the remaining area has a mixed suitability status (suitable for some crops and unsuitable for others) for all the analyzed crops. More than $90 \%$ of the area is suitable for Cicer arietinium, Psidium guajava, Mangifera indica, Citrus spps., Persea americana, Hordeum vulgare L, Carica papaya $L$ and Sorghum bicolor L. Moench. However a large portion (71.2\%) of the cultivated land is permanently unsuitable for Olives.

Many options can be raised for the sustainable use of the land for crops and fruit production. 1) Use of crops and fruits, which are categorized as suitable to the area. 2) Correcting some of the limiting factors such as $\mathrm{pH}$ through application of fertilizers which can lower alkalinity effect in the soil (e.g. land unit 1); increasing the soil organic matter through crop residue management and other soil management options (e.g. land units 1, 2 and 3); application of soil and water conservation measures to increase soil depth (e.g. Land unit 2). 3) Changing the land use type (e.g. land unit 4) to other use types such as enclosure.

\section{ACKNOWLEDGEMENT}

Our particular gratitude goes to Mekelle University NORAD II Project for their financial and logistics support; Mr. Kalayu Berhe, Mr. Aregawi Teka, Mr. Kahsay Tadelle, Mr. Yirgalem Gebre and Mr. Eskindir Gidey for their technical support during the field work. We also would like to thank the farmers and village administration of the study site for providing us with valuable information and for their guidance.

\section{REFERENCES}

Addeo, G.G., Guastadisegni \& Pisante, M. 2001. Land and Water Quality for Sustainable and Precision Farming. World Congress on Conservation Agriculture, Madrid.

Al-Mashreki, M.H., Akhir, J.B.M., Rahim, S.A., Desa, K.M., Lihan, T \& Haider, A.R. 2011. Land Suitability Evaluation for Sorghum Crop in the Ibb Governorate, Republic of Yemen Using Remote Sensing And GIS Techniques. Australian Journal of Basic and Applied Sciences, 5(3): 359-368. 
Behzad, M., Algaji, M., Papan, P., Boroomand Nasab, S., Naseri, A.A \& Bavi, A. 2009. Qualitative Evaluation of Land Suitability for Principal Crops in the Gargar Region, Khuzestan Province, Southwest Iran. Asian Journal of Plant Sciences, 8 (1): 28-34.

Briza, Y., Delionardo, F \& Spisni, A. 2001. Land evaluation in the province of Ben Sliman, Morocco, 21st Course Professional Master. Remote Sensing and Natural Resources Evaluation., 10 Nov 2000 - 22 June 2001, IAO Florence, Italy, 21: 62-78.

Bronick, C.J \& Lal, R. 2005. Soil structure and management: a review. Geoderma, 124,3-22.

Burrough, P.A. 1996. Opportunity and Limitation of GIS Based Modeling of Solute Transport at the Regional Scale. In: D.L. Corwi and K. Loage (Eds.), Application of GIS to the Modeling of Non-point source pollutants in the Vadose Zone. SSSA, Madison, WI.

Cesen. 1986. Biomass energy resources. Ministry of Mines, Addis Ababa.

FAO. 1976. A framework for land evaluation. Soils Bulletin, No. 32. FAO, Rome.

FAO. 1984. Land Evaluation for forestry. Forestry Paper 48, FAO, Rome, 123p.

FAO. 1990. Guidelines for soil description. FAO, Rome, 69p.

FAO. 1998. World reference base for soil resources. FAO, Rome, 88p.

Fischer G., Velthuizen, H.V., Shah, M \& Nachtergaele, F. 2002. Global Agro-ecological Assessment for Agriculture in the $21^{\text {st }}$ Century: Methodology and Results. International Institute for Applied Laxenburg, Australia. Food and Agriculture organization of the United Nations Viale delle Terme di Caracalla Rome, Italy.

Francesco, A., Abu El-Ish, B., Pierre, D., Vladan, D., Mirjana, I., Rosa, K \& Babacar. 2003. Land Evaluation in the province of Thies, Senegal. Proceedings of. $23^{\text {rd }}$ Course Professional Master Geomatics \& Natural Resour, Evaluation, Nov. 8, 2002- June 20, 2003, Ministry of Foreign Affairs, Instituto Agronomico Per L’oltremare, Italy, 148p.

Henok, M. 2010. Land Suitability and Crop Suitability Analysis Using Remote Sensing and GIS Application; A case study in Legambo woreda, Ethiopia.

Hunting. 1976. Tigray Rural Development Report. Hemel Hempstead, Hertfordshire, UK: Hunting Technical Service. Int, Wallingford, England.

Kay, B.D \& Angers, D.A. 1999. Soil Structure. In: Handbook of Soil Science. M.E. Sumner, edition, CRC Press, Boca Raton, A-229-A-276pp.

Lal, R. 1994. Sustainable land use systems and soil resilience. In Soil Resilience and Sustainable land use (ed. D.J. Greenland \& I. Szabolcs), Wallingford, UK: CAB International, 41-67pp. 
Liu, Y \& Chen, Y. 2006. Impact of population growth and land-use change on water resources and ecosystems of the arid Tarim River Basin in Western China. International Journal of Sustainable Development \& World Ecology. V.13, 295p.

Moore, G. 2001. Soil Guide. A handbook for understanding and managing agricultural soils. Agriculture Western Australia Bulletin, No. 4343.

Mullen, R., Lentz, E \& Watson, M. 2007. Soil Acidification: How to Lower Soil pH. Extension Fact Sheet. School of Environment and Natural Resources, 2021 Coffey Road, Columbus, Ohio 43210.

SFPT, 2003. Draft Genfel Tabia Land Use Plan. GFA-terra systems.

Smyth, A.J \& Dumanski, J. 1993. An International Framework for Evaluating Sustainable Land Management. World Soil Resources Report 73, FAO, Rome, Italy.

Sokol, B., Federico, B., Marco, F., Imene, M., Rosa, M., Cheikh, M \& Paolo, P. 2004. Land Evaluation in the oud rmel catchment, Tunisia. Proceedings of $24^{\text {th }}$ Course Professional Master Geomatics and natural Resources Evaluation, Nov. 10, 2003 Jun. 23, 2004, Ministry of Foreign Affairs, Instituto Agronomico Per L’oltremare, Italy, 149p.

Sys, C., Van Ranst, E., Debaveye, Ir.J \& Beernaert, F. 1993. Land evaluation, part III. Crop requirements. Agriculture publication, no.7, General Administration for Development Cooperation. Brussels, Belgium, 166p.

Sys, I., Van Ranst E \& Debaveye, J. 1991. Land evaluation, part II. Methods in land evaluation. Agriculture publications, no.7, General Administration for Development Cooperation, Brussels, Belgium, 70-76pp.

Teklu, E.J. 2005. Land Preparation Methods and Soil Quality of a Vertisol Area in the Central Highlands of Ethiopia. PhD Thesis Universitat Hohenheim (310); D70593 Stuttgart.

Van Diepen, C.A., Van Keulen, H., Wolf, J \& Berkhout, J.A.A. 1991. Land evaluation: from intuition to quantification. In: B.A. Stewart (ed.), Advances in Soil Science. Springer, New York, 139-204pp.

Yasmina, A., Moulay, A., Najmia, A.M., Enrico, B., Yasmina, B., Paolo Omar, C \& Aldo, D. 2001. Land Evaluation in the province of Bel Slimane, Morocco. Proceedings of $21^{\text {st }}$ Course Professional Master Geomatics and natural Resources Evaluation, Nov. 10, 2000 - Jun. 22,2001, Ministry of Foreign Affairs, Instituto Agronomico Per L’oltremare, Italy, 148p. 